Primljen / Received: 21.9.2012. Ispravljen / Corrected: 19.2.2013.

Prihvaćen / Accepted: 21.2.2013.

Dostupno online / Available online: 10.5.2013.

\section{Railway embankment design based on neural networks}

Authors:

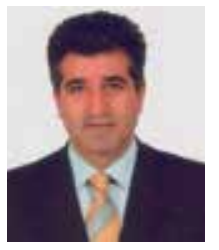

Prof. Gökmen Tayfur, PhD. CE Izmir Institute of Technoloqy Department of Civil Engineering gokmentayfur@iyte.edu.tr

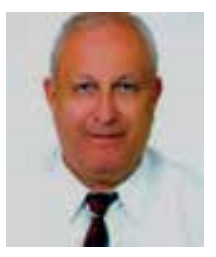

\section{Gökmen Tayfur, İsfendiyar Egeli}

Scientific paper (Preliminary note)

\section{Railway embankment design based on neural networks}

The main requirements in the design of high-speed railway embankments are low values of total differential settlements. The use of cement stabilized layers in embankments, as compared to non-stabilized layers that are now most often in use, is analysed in the paper. Different cement proportions and different water/cement ratios for stabilized layers are considered. It was established that the use of cement stabilized layers in embankments can greatly reduce thickness of individual layers, while also reducing settlement. The research was conducted using the feed forward neural network.

\section{Key words:}

high speed railways, railway embankments, feed forward neural network

\section{Gökmen Tayfur, İsfendiyar Egeli}

Znanstveni rad (Prethodno priopćenje)

\section{Projektiranje nasipa željezničkih pruga primjenom neuronskih mreža}

Prof. İsfendiyar Egeli, PhD. CE Izmir Institute of Technoloqy Department of Civil Engineering isfendiyaregeli@iyte.edu.tr
Osnovni zahtjev pri projektiranju nasipa željezničkih pruga za velike brzine su male vrijednosti ukupnih diferencijalnih slijeganja. U radu se analizira primjena cementom stabiliziranih slojeva u nasipima u odnosu na nestabilizirane slojeve koji se najčešče koriste. Razmatrani su različiti udjeli cementa te različiti vodocementni faktori u stabiliziranom sloju. Dobiveno je da primjena cementom stabiliziranih slojeva u nasipima može značajno smanjiti debljinu pojedinih slojeva te smanjiti slijeganja. Istraživanje je provedeno primjenom prema naprijed usmjerene neuronske mreže.

Ključne riječi:

željeznice za velike brzine, željeznički nasipi, prema naprijed usmjerena neuronska mreža (FFNN)

Wissenschaftlicher Originalbeitrag (Vorherige Mitteilung)

\section{Gökmen Tayfur, İsfendiyar Egeli}

\section{Entwurf von Eisenbahndämmen durch die Anwendung neuronaler Netze}

Die Grundanforderung beim Entwurf von Eisenbahndämmen für Hochgeschwindigkeitszüge sind eingeschränkte Werte der gesamten ungleichmäßigen Setzungen. In der vorliegenden Arbeit wird die Anwendung von mit Zement stabilisierten Unterbauschichten im Vergleich zu herkömmlichen Schichten ohne Stabilisierung untersucht. Der Gebrauch verschiedener Zementanteile und Wasserzementwerte in der stabilisierten Schicht ist betrachtet worden. Die Ergebnisse lassen darauf schließen, dass durch die Verwendung mit Zement stabilisierter Schichten, die Abmessungen der einzelnen Schichten bedeutend reduziert und Setzungen vermindern werden können. Für die gegebenen Untersuchungen sind vorwärts gerichtete neuronale Netze angewandt worden. 


\section{Introduction}

Travelling by high-speed railways is nowadays increasingly becoming a desirable mode of transport as such railway systems inter alia enable travelling at high-speed, combined with high level of safety and comfort. The design of highspeed railway embankments (HSRE) differs from the design of embankments for traditional railways in the following elements: greater dimensions are needed, more stringent material quality requirements are specified, and very small total settlement values are tolerated [1-6]. For the time being, high-speed railways are built in a small number of countries, mostly in Europe and Far East (China, Japan, South Korea). A typical cross-section of a traditional track structure (track with ballast prism) is shown in Figure 1, while a typical cross-section of track structure on hard bedding, which is most often used on high-speed tracks in Far East [1], is shown in Figures 2 and 3 . A longitudinal section of high-speed railways is shown

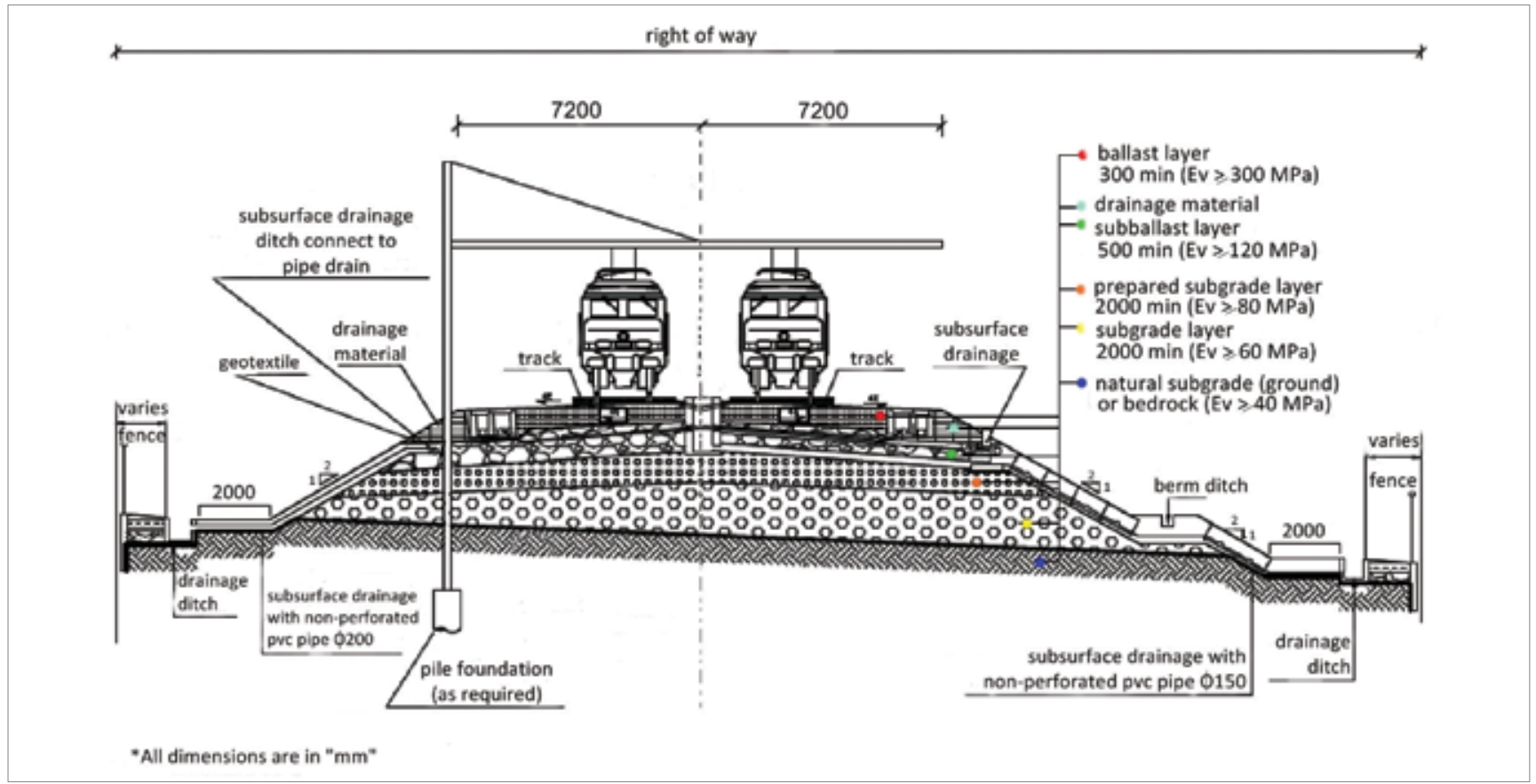

Figure 1. Cross-section of a typical embankment used on European high-speed railways (traditional track structure)

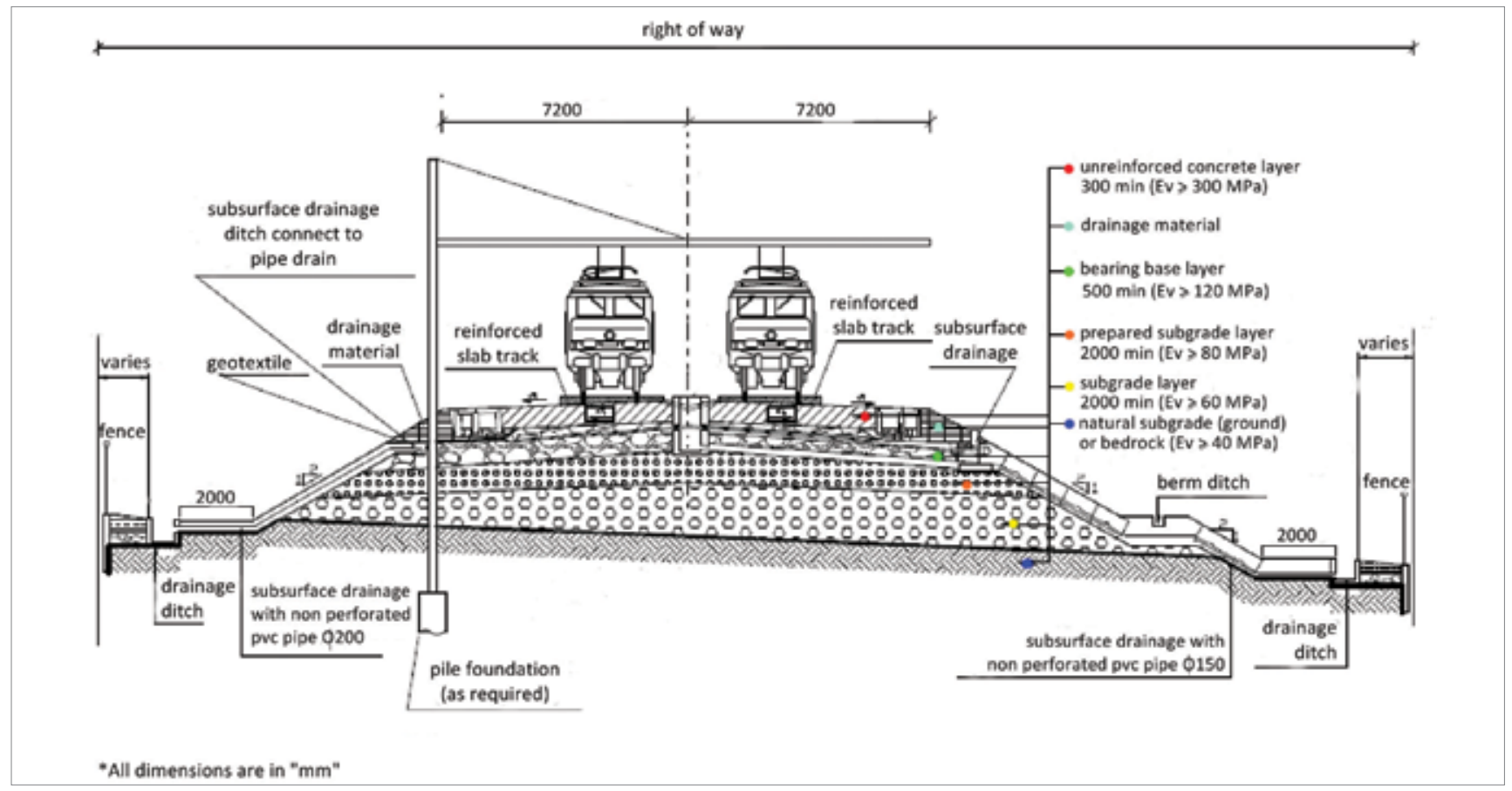

Figure 2. Cross-section of a typical embankment used on high-speed railways in the Far East 


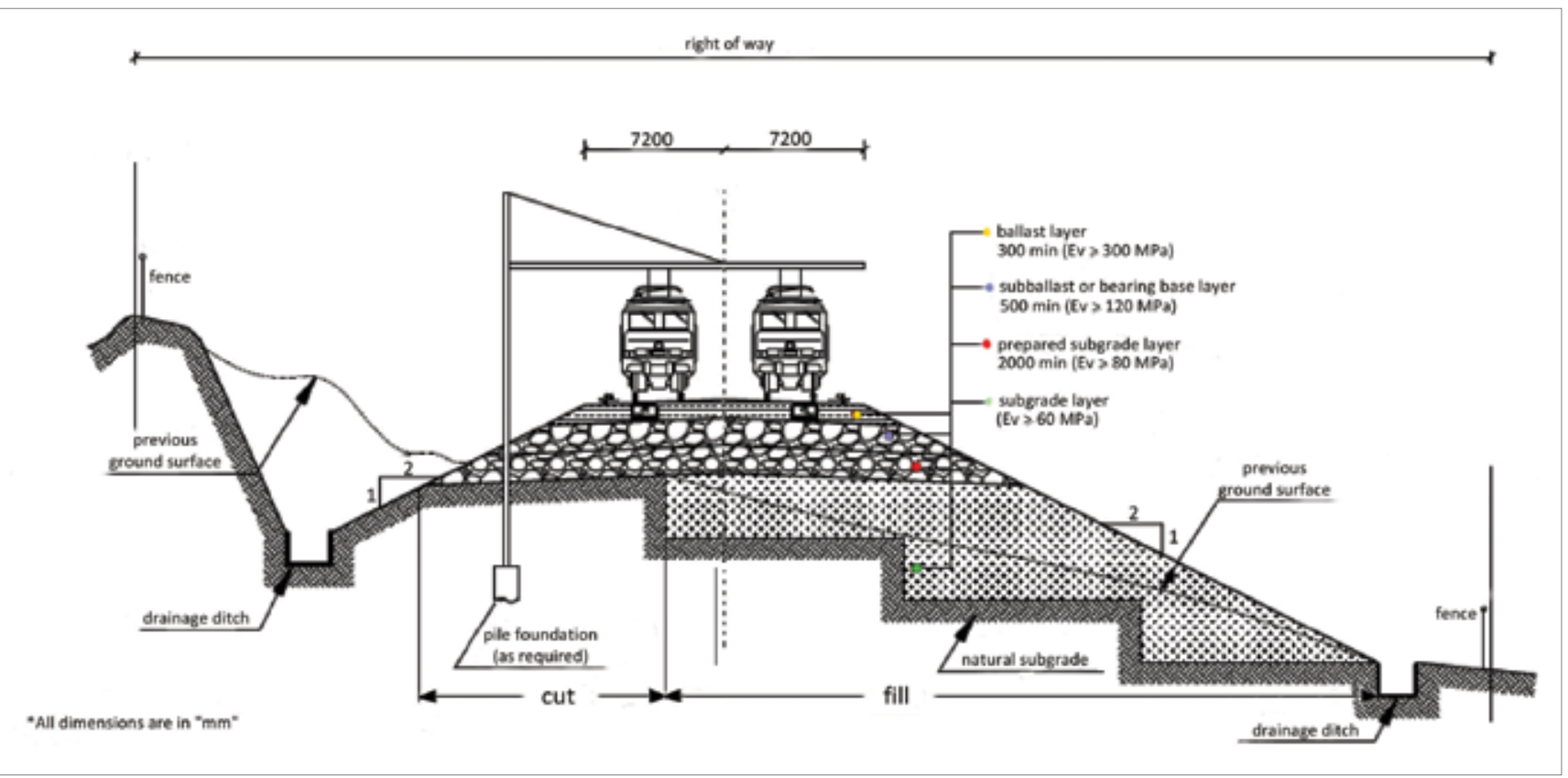

Figure 3. Cross-section of a typical side cut used on high-speed railways in the Far East

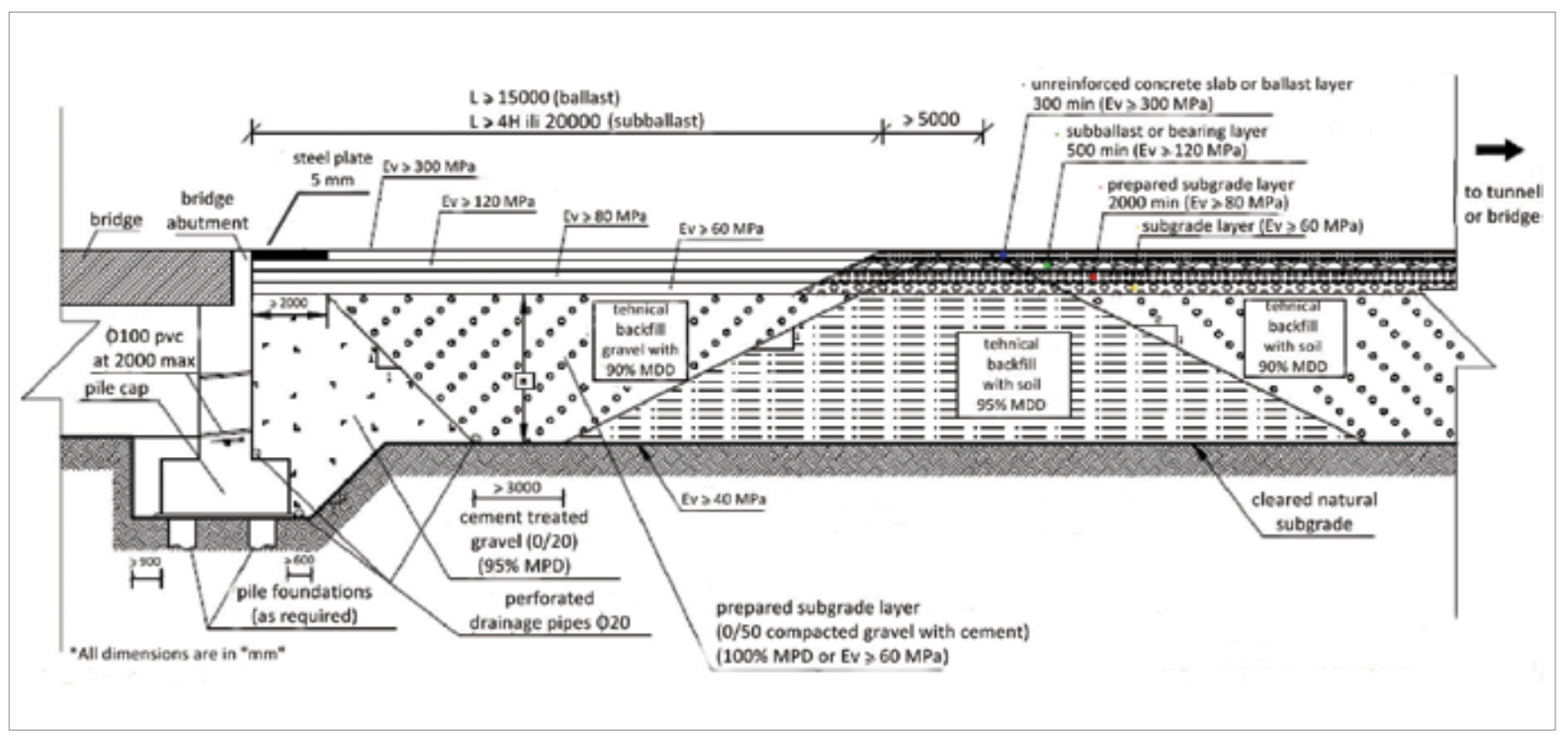

Figure 4. Typical high-speed railway longitudinal section used in the Far East

in Figure 4. In both systems, the layer stiffness increased from the bottom layers toward the top layers. Standard track substructure layers are: natural soil, subgrade, stabilized layer, and load-bearing layer. In case of a traditional track structure, the load-bearing layer is topped by the subbase, ballast prism, and track structure. In case of a track on solid bedding, the loadbearing layer is topped by concrete bedding, which is the base for a particular type of a rigid track structure.

In practical terms, we are often faced with situations in which the width of the railway strip is not sufficient for the construction of 2:1 slopes. This is solved either by additional land purchase or by building stabilized embankment layers so as to permit steeper slope inclinations. Although the cost of building traditional structures is lower, the maintenance cost is higher. On the other hand, in case of tracks on hard base, higher construction costs are offset by lower maintenance costs [7].

The embankment construction system for tracks on hard base, destined for high speeds of travel, is analysed in this paper. In this system, one embankment layer that is normally not stabilized with cement (uncemented-prepared subgrade layer or U-PSL) is replaced by the load-bearing layer stabilized with cement (cemented-prepared subgrade layer or C-PSL) [1]. 


\section{Experimental data}

Characteristics of material used for preparation of the loadbearing layer not stabilized with cement (U-PSL) are presented in Table 1 [1]. Proportions of individual fractions in the grain size distribution of material used for preparation of the load bearing layer are presented in the table. Properties of this material are checked in accordance with national regulations [8-12] and international test standards [5, 6]. These are the Standard Proctor Test (ASTM D 698-00) to determine the maximum dry density (MDD) and the optimum moisture content (OMC), and the Plate Bearing Test (ASTM D 1196-93, 2004), where the maximum particle size should be smaller than $100 \mathrm{~mm}$. The laboratory test requirements are such that the relative compaction with respect to maximum dry density (MDD) from the Standard Proctor Test $\left(\rho_{d}\right)$ should not exceed $95 \%$ and the vertical Elastic modulus from the Plate Bearing Test $\left(\mathrm{E}_{\mathrm{v}}\right)$ should not be greater than 80MPa. Results of laboratory tests conducted on a typical U-PSL material (obtained locally) are given in Table 2 [12].

Locally obtained Turgutlu medium sand, and the Type-1 Portland cement (ASTM C150, 1994), were used to establish appropriate mix proportions at two water-cement ratios $(40 \%, 50 \%)$ with five cement content values $(10,15,20$, $25,30 \%$ for laboratory samples. Three different diameter cylindrical samples were prepared in steel molds and were then water-cured for 7 and 28 days, before being subjected to the unconfined compression strength testing aimed at determining their uniaxial compressive strength values (according to local standards TS EN 12390-2, 2002; -3, 2003) [8-12]. Design requirements (ie. the limiting values) of the mix are given in Table 3 [13].
Table 1. Limit grading values for material to be placed on embankment as a load bearing layer

\begin{tabular}{|c|c|}
\hline Grain Size $^{* *}$ & Percentage passing \\
\hline$P(2 D)$ & 100 \\
\hline$P\left(D_{\text {max }}\right)$ & $100-99$ \\
\hline$P(D)$ & $99-85$ \\
\hline$P(D / 2)$ & $84-55$ \\
\hline$P(D / 5)$ & $60-31$ \\
\hline$P(D / 10)$ & $49-23$ \\
\hline$P(D / 20)$ & $40-17$ \\
\hline$P(D / 50)$ & $31-11$ \\
\hline$P(D / 100)$ & $22-8$ \\
\hline$P(D / 200)$ & $16-6$ \\
\hline$P(D / 500)$ & $9-3$ \\
\hline$P(D / 1000)$ & $6-2$ \\
\hline$\left.{ }^{*}\right)$ Note: $D=$ nominal grain size \\
$D_{\text {max }}=1.25 D$, if $D \geq 50$ mm \\
$D_{\text {max }}=1.58 D$, if $D<50$ mm & \\
\hline
\end{tabular}

Table 3. Design values for the prepared mixes of C-PSL

\begin{tabular}{|c|c|}
\hline Name & Value \\
\hline Slump & $70 \mathrm{~mm}$ \\
\hline Max. size of aggregate & $50 \mathrm{~mm}$ \\
\hline Mixing water and air content & depends on w/c \\
\hline Water/Cement ratio (w/c) & $0.4-0.5$ \\
\hline Cement content [\%] & $10,15,20,25,30 \%$ \\
\hline Coarse aggregatecontent & depends on w/c \\
\hline
\end{tabular}

Table 2. Laboratory test results for material used in embankment layers not stabilised with cement

\begin{tabular}{|c|c|c|c|}
\hline Tested property & Used method & ASTM-D & Value \\
\hline Particle Size Analysis & Wet Sieve Analysis & $\begin{array}{l}\text { ASTM-D } \\
422-63\end{array}$ & - \\
\hline $\begin{array}{l}\text { The laboratory } \\
\text { Compaction Test }\end{array}$ & Standard Proctor Method & $\begin{array}{l}\text { ASTM-D } \\
698-00\end{array}$ & $\begin{array}{c}W_{\text {opt }}=13.6[\%] \\
\gamma_{\text {drymax }}=19,994\left[\mathrm{kN} / \mathrm{m}^{3}\right]\end{array}$ \\
\hline Specific Gravity of Soil Solids & Pycnometer Method & $\begin{array}{l}\text { ASTM-D } \\
854-02\end{array}$ & 2.65 \\
\hline Determination of Water Content & Oven Dried Method & $\begin{array}{l}\text { ASTM-D } \\
2216\end{array}$ & $\begin{array}{c}3.3[\%] \\
\text { Laboratory conditions }\end{array}$ \\
\hline $\begin{array}{c}\text { Classification of Soil for Engineering } \\
\text { Purposes }\end{array}$ & USCS & $\begin{array}{l}\text { ASTM-D } \\
2487-00\end{array}$ & SP \\
\hline Coefficient of Permeability & Falling Head Method & $\begin{array}{l}\text { ASTM-D } \\
\text { 5084-03 }\end{array}$ & $10^{-3}[\mathrm{~m} / \mathrm{s}]$ \\
\hline Maximum Index Density & Vibration Table Method & $\begin{array}{l}\text { ASTM-D } \\
4253-00\end{array}$ & - \\
\hline Triaxial Compression Test & Consolidated-Drained (CD) & $\begin{array}{c}\text { ASTM } \\
\text { WK3821 }\end{array}$ & $\begin{array}{c}c=7[\mathrm{kPa}] \\
\theta=37\left[^{\circ}\right]\end{array}$ \\
\hline Direct Shear Test & Consolidated-Drained (CD) & $\begin{array}{l}\text { ASTM-D } \\
3080-04\end{array}$ & $\begin{array}{c}\mathrm{C}=7[\mathrm{kPa}] \\
\theta=36.88\left[{ }^{\circ}\right]\end{array}$ \\
\hline
\end{tabular}


Three sample sets were prepared and, at that, the first group (group $A$ ) was prepared as a small sample size ( $D=4$ $\mathrm{cm}, \mathrm{H}=8 \mathrm{~cm}$ ), the second group (group $\mathrm{B}$ ) as a medium sample size $(D=8 \mathrm{~cm}, H=16 \mathrm{~cm})$, and the third group (group $C$ ) as a large sample size $(D=10 \mathrm{~cm}, H=20 \mathrm{~cm})$. Thus, three sets with three specimens in each set were prepared. The first set was tested after 7 days of water curing, and the other two sets were tested after 28 days of cure. The total of 180 specimens were prepared. These specimens were divided into three groups, each with five different cement contents $(10 \%, 15 \%, 20 \%, 25 \%, 30 \%)$ and two different water-cement ratios, $w / c$ ( 0.4 and 0.5$)$. Thirty specimens tested after 28 days of cure, and thirty specimens tested after 7 days of cure, were used for the unconfined compressive strength testing. The testing was conducted at the IYTE-MAM Laboratory using the universal (static) testing machine. As the analysis does not include the material aging effect for the composite materials subjected to long term dynamic load, further research might be oriented toward preparation of the same samples to be tested under dynamic load (using dynamic uniaxial or triaxial testing machines) which would simulate dynamic train loads. Experimental test results are given in Tables 4 and 5.

\section{Settlement analyses}

According to Far-Eastern HSR design practice, considering the design speed ranging between $200-400 \mathrm{~km} / \mathrm{hr}$, and under a passing wheel load of about $200 \mathrm{kN}$, two settlement requirements are given [1];

- In any lateral section of the track (Figs. 2 and 3), the maximum long term total top-of-rail $(\Delta z)$ settlements, or the maximum long term differential settlements between rails, should not exceed $2 \mathrm{~mm}$.

Table 4. Experimental data (first sample group)

\begin{tabular}{|c|c|c|c|c|c|c|c|c|}
\hline $\begin{array}{l}\text { Sample } \\
\text { group }\end{array}$ & $\begin{array}{c}\text { D } \\
{[\mathrm{cm}]}\end{array}$ & $\begin{array}{c}\mathrm{H} \\
{[\mathrm{cm}]}\end{array}$ & $w / c$ & $\begin{array}{c}\text { Cement } \\
\text { content } \\
{[\%]}\end{array}$ & $\begin{array}{c}\text { Cure } \\
\text { [days] }\end{array}$ & $\begin{array}{c}\text { Stress at } \\
\text { failure } \\
{[\mathrm{MPa}]}\end{array}$ & $\begin{array}{c}\text { Elastic } \\
\text { modulus } \\
{[\mathrm{MPa}]}\end{array}$ & $\begin{array}{c}\text { Strain at } \\
\text { failure } \\
{[\%]}\end{array}$ \\
\hline $1 \mathrm{~A}$ & 4 & 8 & 0.5 & 15 & 28 & 2,009 & 42,410 & 4,736 \\
\hline $1 \mathrm{~B}$ & 8 & 16 & 0.5 & 15 & 28 & 2,945 & 50,460 & 5,835 \\
\hline $1 \mathrm{C}$ & 10 & 20 & 0.5 & 15 & 28 & 2,008 & 40,310 & 4,982 \\
\hline $2 A$ & 4 & 8 & 0.5 & 20 & 28 & 6,108 & 103,200 & 5,919 \\
\hline $2 \mathrm{~B}$ & 8 & 16 & 0.5 & 20 & 28 & 8,055 & 109,460 & 7,359 \\
\hline $2 C$ & 10 & 20 & 0.5 & 20 & 28 & 11,870 & 145,680 & 8,148 \\
\hline $3 A$ & 4 & 8 & 0.5 & 10 & 28 & 1,243 & 25,290 & 4,916 \\
\hline 3B & 8 & 16 & 0.5 & 10 & 28 & 1,990 & 37,030 & 5,373 \\
\hline $3 C$ & 10 & 20 & 0.5 & 10 & 28 & 2,669 & 44,620 & 5,982 \\
\hline $4 A$ & 4 & 8 & 0.5 & 25 & 28 & 11,016 & 205,480 & 5,361 \\
\hline $4 B$ & 8 & 16 & 0.5 & 25 & 28 & 15,734 & 289,850 & 5,428 \\
\hline $4 C$ & 10 & 20 & 0.5 & 25 & 28 & 11,017 & 181,160 & 6,081 \\
\hline $5 A$ & 4 & 8 & 0.5 & 30 & 28 & 0.547 & 271,840 & 4,788 \\
\hline $5 B$ & 8 & 16 & 0.5 & 30 & 28 & 0.767 & 317,590 & 5,171 \\
\hline $5 C$ & 10 & 20 & 0.5 & 30 & 28 & 1,121 & 329,650 & 5,324 \\
\hline $6 \mathrm{~A}$ & 4 & 8 & 0.4 & 15 & 28 & 1,002 & 18,210 & 5,201 \\
\hline $6 \mathrm{~B}$ & 8 & 16 & 0.4 & 15 & 28 & 1,441 & 25,480 & 5,354 \\
\hline $6 C$ & 10 & 20 & 0.4 & 15 & 28 & 2,519 & 43,470 & 5,495 \\
\hline $7 A$ & 4 & 8 & 0.4 & 20 & 28 & 4,247 & 92,140 & 5,109 \\
\hline $7 \mathrm{~B}$ & 8 & 16 & 0.4 & 20 & 28 & 5,588 & 110,510 & 5,257 \\
\hline $7 C$ & 10 & 20 & 0.4 & 20 & 28 & 8,920 & 171,080 & 5,214 \\
\hline $8 \mathrm{~A}$ & 4 & 8 & 0.4 & 10 & 28 & 12,201 & 11,250 & 4,960 \\
\hline $8 B$ & 8 & 16 & 0.4 & 10 & 28 & 14,836 & 14,790 & 5,188 \\
\hline $8 C$ & 10 & 20 & 0.4 & 10 & 28 & 15,902 & 20,660 & 5,424 \\
\hline $9 A$ & 4 & 8 & 0.4 & 25 & 28 & 10,919 & 232,800 & 4,690 \\
\hline $9 \mathrm{~B}$ & 8 & 16 & 0.4 & 25 & 28 & 12,284 & 229,000 & 5,364 \\
\hline $9 \mathrm{C}$ & 10 & 20 & 0.4 & 25 & 28 & 13,126 & 240,290 & 5,462 \\
\hline $10 A$ & 4 & 8 & 0.4 & 30 & 28 & 15,078 & 313,820 & 4,805 \\
\hline $10 \mathrm{~B}$ & 8 & 16 & 0.4 & 30 & 28 & 17,952 & 353,470 & 5,079 \\
\hline $10 C$ & 10 & 20 & 0.4 & 30 & 28 & 21,208 & 421,260 & 5,035 \\
\hline
\end{tabular}


Table 5. Experimental data (second sample group)

\begin{tabular}{|c|c|c|c|c|c|c|c|c|}
\hline $\begin{array}{l}\text { Sample } \\
\text { group }\end{array}$ & $\begin{array}{c}\text { D } \\
{[\mathrm{cm}]}\end{array}$ & $\begin{array}{c}\mathrm{H} \\
{[\mathrm{cm}]}\end{array}$ & $w / c$ & $\begin{array}{c}\text { Cement } \\
\text { content } \\
{[\%]}\end{array}$ & $\begin{array}{l}\text { Cure } \\
\text { [days] }\end{array}$ & $\begin{array}{c}\text { Stress at } \\
\text { failure } \\
\text { [MPa] }\end{array}$ & $\begin{array}{c}\text { Elastic } \\
\text { modulus } \\
{[\mathrm{MPa}]}\end{array}$ & $\begin{array}{c}\text { Strain at } \\
\text { failure } \\
{[\%]}\end{array}$ \\
\hline $1 \mathrm{~A}$ & 4 & 8 & 0,5 & 15 & 7 & 1,456 & 25,409 & 3,541 \\
\hline $1 \mathrm{~B}$ & 8 & 16 & 0,5 & 15 & 7 & 2,162 & 49,826 & 3,923 \\
\hline $1 C$ & 10 & 20 & 0,5 & 15 & 7 & 2,753 & 77,271 & 3,260 \\
\hline $2 A$ & 4 & 8 & 0,5 & 20 & 7 & 4,506 & 87,754 & 6,063 \\
\hline $2 \mathrm{~B}$ & 8 & 16 & 0,5 & 20 & 7 & 7,277 & 131,308 & 6,607 \\
\hline $2 C$ & 10 & 20 & 0,5 & 20 & 7 & 9,783 & 226,891 & 6,343 \\
\hline $3 A$ & 4 & 8 & 0,5 & 10 & 7 & 0,911 & 10,964 & 4,834 \\
\hline $3 B$ & 8 & 16 & 0,5 & 10 & 7 & 1,412 & 12,713 & 4,810 \\
\hline $3 C$ & 10 & 20 & 0,5 & 10 & 7 & 2,073 & 15,723 & 5,218 \\
\hline $4 \mathrm{~A}$ & 4 & 8 & 0,5 & 25 & 7 & 7,757 & 217,926 & 4,491 \\
\hline $4 \mathrm{~B}$ & 8 & 16 & 0,5 & 25 & 7 & 12,52 & 282,256 & 4,719 \\
\hline $4 C$ & 10 & 20 & 0,5 & 25 & 7 & 15,137 & 376,064 & 4,968 \\
\hline $5 A$ & 4 & 8 & 0,5 & 30 & 7 & 12,213 & 376,527 & 3,428 \\
\hline $5 B$ & 8 & 16 & 0,5 & 30 & 7 & 14,977 & 548,467 & 3,826 \\
\hline $5 C$ & 10 & 20 & 0,5 & 30 & 7 & 16,11 & 801,863 & 4.20 \\
\hline $6 \mathrm{~A}$ & 4 & 8 & 0,4 & 15 & 7 & 1,063 & 18,068 & 4,559 \\
\hline $6 \mathrm{~B}$ & 8 & 16 & 0,4 & 15 & 7 & 1,49 & 31,713 & 4,889 \\
\hline $6 C$ & 10 & 20 & 0,4 & 15 & 7 & 2,48 & 59,204 & 4,874 \\
\hline $7 A$ & 4 & 8 & 0,4 & 20 & 7 & 4,363 & 84,910 & 4,099 \\
\hline $7 \mathrm{~B}$ & 8 & 16 & 0,4 & 20 & 7 & 5,643 & 133,558 & 5,051 \\
\hline $7 C$ & 10 & 20 & 0,4 & 20 & 7 & 8,98 & 259,747 & 4,349 \\
\hline $8 \mathrm{~A}$ & 4 & 8 & 0,4 & 10 & 7 & 0,383 & 135,882 & 4,076 \\
\hline $8 B$ & 8 & 16 & 0,4 & 10 & 7 & 0,694 & 229,160 & 4,320 \\
\hline $8 C$ & 10 & 20 & 0,4 & 10 & 7 & 0,828 & 314,502 & 5,929 \\
\hline $9 A$ & 4 & 8 & 0,4 & 25 & 7 & 7,129 & 245,592 & 3,718 \\
\hline $9 \mathrm{~B}$ & 8 & 16 & 0,4 & 25 & 7 & 11,85 & 390,017 & 4,022 \\
\hline $9 \mathrm{C}$ & 10 & 20 & 0,4 & 25 & 7 & 13,323 & 590,704 & 4,494 \\
\hline $10 \mathrm{~A}$ & 4 & 8 & 0,4 & 30 & 7 & 7,909 & 10,615 & 3,691 \\
\hline $10 \mathrm{~B}$ & 8 & 16 & 0,4 & 30 & 7 & 13,077 & 11,553 & 3,956 \\
\hline $10 C$ & 10 & 20 & 0,4 & 30 & 7 & 11,367 & 13,395 & 4,127 \\
\hline
\end{tabular}

- In any $20 \mathrm{~m}$ long longitudinal section of the track (Figure 4) the maximum total long term settlement, or the maximum long term differential settlement, should not exceed 10 $\mathrm{mm}$.

Long term usually refers to a service life (during operation and after construction) of 30 years [1]. Settlements are calculated from the "natural subgrade level" up to the top of rails, by adding the individual settlements of each layer, except the contribution from steel parts and their connections (i.e. rails and fasteners), which is considered as "rigid" and ignored.

If the above mentioned settlement limits are exceeded, serious safety risks are incurred, which may result in derailing. On the other hand, constructing the rail-track structure on a very rigid (non-settling) embankment may cause reduced riding comfort and increased "wear-and-tear" of tracks with train undercarriage, including wheels.

The embankment settlement analysis is made in the paper, and the possibility of replacing the mechanically stabilised $2 \mathrm{~m}$ thick load-bearing layer having $\mathrm{E}_{v}=80 \mathrm{MPa}$, with the cement stabilized load-bearing layer, is considered. The thickness and elastic modulus values of the cement-stabilized load-bearing layer were varied, while moduli were obtained from uniaxial compression testing (Tables 4 and 5) conducted after 7 and 28 days of cure. The program Plaxis V8 (2D) FEM was used in the embankment settlement analysis, using the following procedure:

a) First, the railway embankment was modelled for high speeds (Figure 5).

b) In a typical HSRE, there are four different fill layers, above the natural subgrade layer and below the "topof-rails" (Figures 2-4). Although all these layers have different material properties and conditions (Table 6), they were considered in the analyses as non-changing. The properties of individual layers were introduced in the analysis because the aim was to replace a usual $2 \mathrm{~m}$ thick unstabilized layer (U-PSL) (which is one of four sublayers) with the cement stabilized layer (by varying layer properties depending on cement content) (C-PSL) whose values are shown in Table 7. For simplicity reasons, it was assumed that the ground water table (GWT) is below the natural subgrade level.

c) A finite element mesh was generated for the HSRE model considered (Figure 6). 


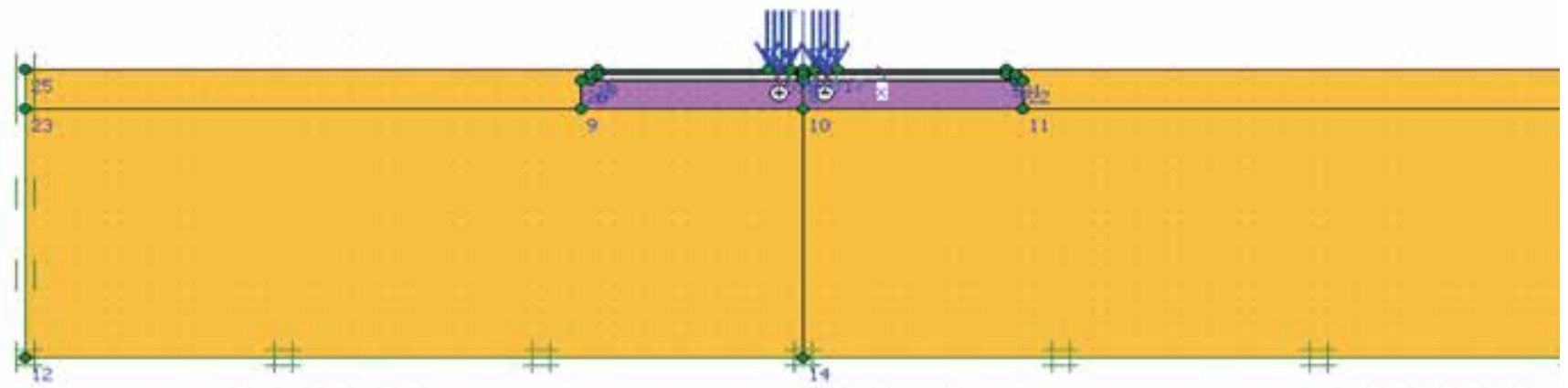

Figure 5. HSRE model adopted

Table 6. Material properties for the adopted HSRE model

\begin{tabular}{|c|c|c|c|c|c|}
\hline Parameter & Name & Slab track layer & $\begin{array}{c}\text { Bearing base } \\
\text { layer }\end{array}$ & $\begin{array}{c}\text { Prepared } \\
\text { subgrade layer }\end{array}$ & Subgrade layer \\
\hline Material model & & Mohr-Coulomb & Mohr-Coulomb & Mohr-Coulomb & Mohr-Coulomb \\
\hline Material behavior & & suh & suh & suh & suh \\
\hline Soil (dry) unit weight $\left[\mathrm{kN} / \mathrm{m}^{3}\right]$ & $\gamma_{\text {unsat. }}$ & 19 & 18 & 17 & 16 \\
\hline Soil (wet) unit weight [kN/m³] & $\gamma_{\text {sat. }}$ & 22 & 21 & 20 & 19 \\
\hline Horizontal Permeability [m/s] & $\mathrm{k}_{\mathrm{h}}$ & 0.2 & $3 \times 10^{-2}$ & $10^{-3}$ & $10^{-5}$ \\
\hline Vertical Permeability [m/s] & $\mathrm{k}_{\mathrm{v}}$ & 0.2 & $3 \times 10^{-2}$ & $10^{-1}$ & $10^{-5}$ \\
\hline Young's Modulus [kPa] & $E_{v(r e f)}$ & $300 \times 10^{3}$ & $120 \times 10^{3}$ & $80 \times 10^{3(*)}$ & $60 \times 10^{3}$ \\
\hline Poisson's Ratio & u & 0.40 & 0.35 & 0.30 & 0.2 \\
\hline Cohesion [kPa] & $\mathrm{c}_{\mathrm{ref}}$ & 1 & 1.5 & 7 & 5 \\
\hline Friction angle $\left[{ }^{\circ}\right]$ & $\emptyset^{\prime}$ & 40 & 38 & 37 & 35 \\
\hline Dilatancy angle $\left[{ }^{\circ}\right]$ & $\Psi$ & - & - & 2 & - \\
\hline
\end{tabular}

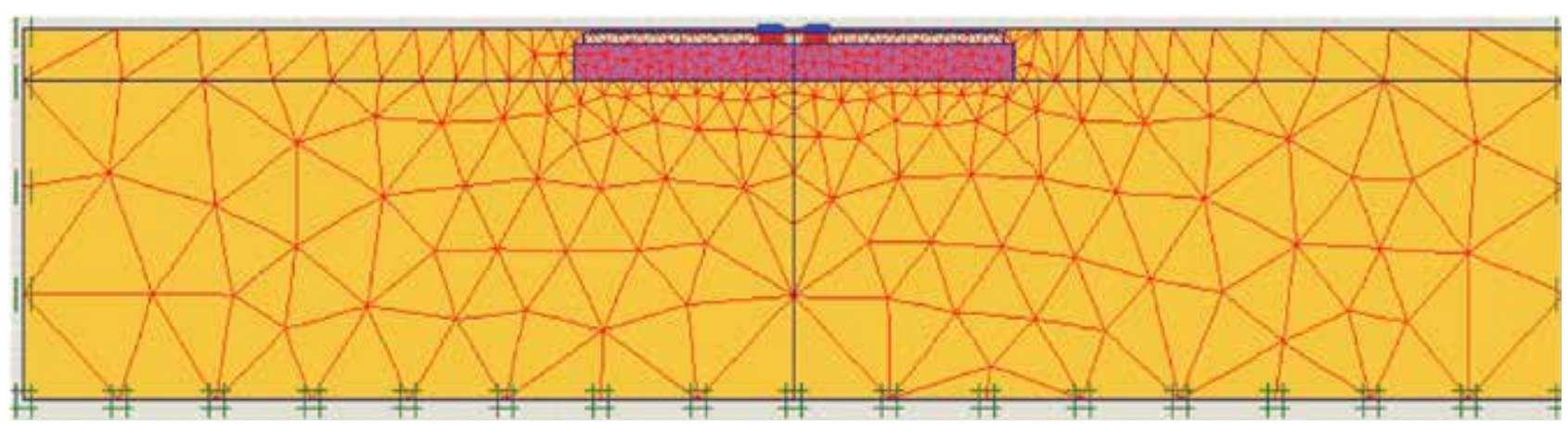

Figure 6. Finite element mesh

d) Six elastic moduli were obtained for the cementstabilized bearing layer (C-PSL). These moduli are presented in Table 7. Two water-to cement ratios (0.4 and 0.5$)$ and three cement contents $(C=20,25,30$ $\%)$ were varied to obtain the elastic modulus. Tests done for the lower cement contents of $10 \%$ and $15 \%$ were discounted, as they did not meet the criteria of equalling or exceeding the required minimum elastic modulus value of $80 \mathrm{MPa}$.
Table 7. C-PSL elastic moduli variation with water/cement (w/c) ratios and cement contents, $C(\%)$

\begin{tabular}{|c|c|c|c|}
\hline \multicolumn{4}{|c|}{ Elastic modulus, $\mathrm{E}_{\mathrm{v}}[\mathrm{MPa}]$} \\
\hline \multirow{3}{*}{$\mathrm{v} / \mathrm{C}$} & \multicolumn{3}{|c|}{ Cement content } \\
\cline { 2 - 4 } & $20 \%$ & $25 \%$ & $30 \%$ \\
\hline 0,5 & 258.94 & 261.46 & 450.47 \\
\hline 0,4 & 352.86 & 545.20 & 597.48 \\
\hline
\end{tabular}




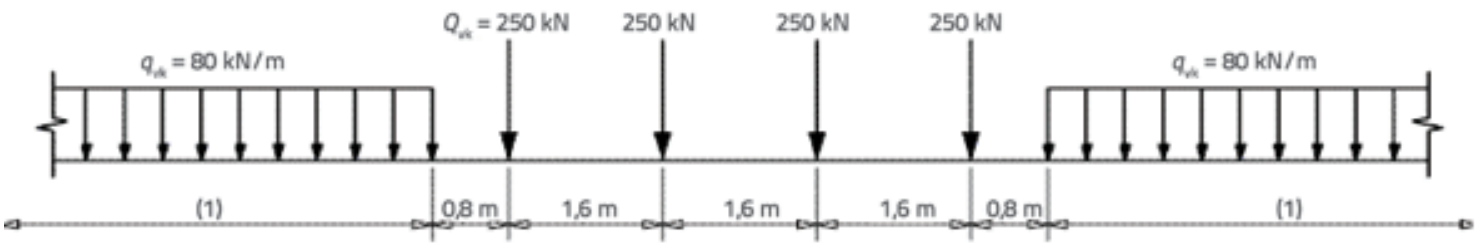

Figure 7. Load model 71 and vertical load in the longitudinal direction of a embankment

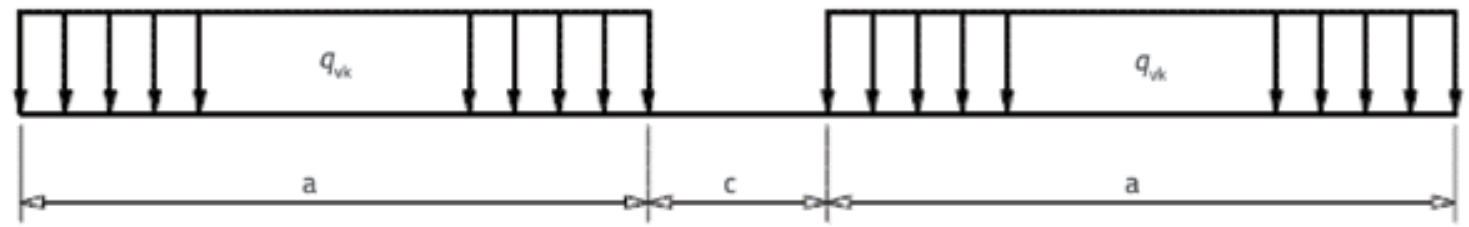

Figure 8. Load Model SW/O and vertical load in the longitudinal direction of a embankment

e) The EN 1991-2: Eurocode 1 was used for the static load intensity $\left(q_{v k}\right)$, [2]. In this standard, the rail traffic load is defined by means of load models. Instead of the load model 71 with distance (1) having no limitation (but usually taken as $21.5 \mathrm{~m}$ ), a more reliable load model SW/O (Figure 8) was used to represent the static effect of vertical load caused by normal rail traffic on most railway embankments. It should be noted that the analysis does not include the material aging effect for composite materials subjected to long term dynamic load. Characteristic values of "a", " $c$ " and "1" for the model SW/0 and the model 71 are given in Table $8[1,2]$.
Table 8. Characteristic values for load models SW/0 and 71

\begin{tabular}{|c|c|c|c|c|}
\hline Load model & $\begin{array}{c}\mathrm{q}_{\mathrm{vk}} \\
{[\mathrm{kN} / \mathrm{m}]}\end{array}$ & $\begin{array}{c}\mathrm{a} \\
{[\mathrm{m}]}\end{array}$ & $\begin{array}{c}\mathbf{c} \\
{[\mathrm{m}]}\end{array}$ & $\begin{array}{c}(1) \\
{[\mathrm{m}]}\end{array}$ \\
\hline $\mathrm{SW} / 0$ & 133 & 15.0 & 5.3 & - \\
\hline 71 & - & - & - & 21.5 \\
\hline
\end{tabular}

f) Finally, total settlements were calculated using the Plaxis-FEM program by varying six different laboratory obtained elastic moduli of the cement-stabilized layer (C-PSL), as listed in Table 5. Results compared with the minimum value of $E_{v}=80 \mathrm{MPa}$ for the cement-stabilized layer are presented in Table 9.

Table 9. Total settlement results for each of the six cement stabilised mixes (C-PSL) which replace the load-bearing layer (U-PSL) $2 \mathrm{~m}$ in thickness

\begin{tabular}{|c|c|c|c|c|c|c|c|c|}
\hline \multirow[b]{2}{*}{ Layers } & \multirow{2}{*}{\begin{tabular}{|c|}
$\begin{array}{c}\text { Uncemented } \\
\text { prepared } \\
\text { subgrade layer } \\
\text { (U-PSL) }\end{array}$ \\
\\
$\Delta \mathrm{S}_{1}$ \\
$\mathrm{E}=80 \mathrm{MPa}$ \\
{$[\mathrm{mm}]$}
\end{tabular}} & \multicolumn{6}{|c|}{ Cemented-prepared subgrade layer (C-PSL) } & \multirow[b]{2}{*}{$\begin{array}{l}\mathrm{TTS}^{(*)} \\
{[\mathrm{mm}]}\end{array}$} \\
\hline & & $\begin{array}{c}\Delta \mathrm{S}_{2} \\
\mathrm{v} / \mathrm{c}=0.4 \\
\mathrm{C}=20 \% \\
\mathrm{E}=352.9 \mathrm{MPa} \\
{[\mathrm{mm}]}\end{array}$ & $\begin{array}{c}\Delta \mathrm{S}_{3} \\
\mathrm{v} / \mathrm{c}=0.4 \\
\mathrm{C}=25 \% \\
\mathrm{E}=545.2 \mathrm{MPa} \\
{[\mathrm{mm}]}\end{array}$ & $\begin{array}{c}\Delta \mathrm{S}_{4} \\
\mathrm{v} / \mathrm{c}=0.4 \\
\mathrm{C}=30 \% \\
\mathrm{E}=597.5 \mathrm{MPa} \\
{[\mathrm{mm}]}\end{array}$ & $\begin{array}{c}\Delta \mathrm{S}_{5} \\
\mathrm{v} / \mathrm{c}=0.5 \\
\mathrm{C}=20 \% \\
\mathrm{E}=258.9 \mathrm{MPa} \\
{[\mathrm{mm}]}\end{array}$ & $\begin{array}{c}\Delta \mathrm{S}_{6} \\
\mathrm{v} / \mathrm{c}=0.5 \\
\mathrm{C}=25 \% \\
\mathrm{E}=261.5 \mathrm{MPa} \\
{[\mathrm{mm}]}\end{array}$ & $\begin{array}{c}\Delta \mathrm{S}_{7} \\
\mathrm{v} / \mathrm{c}=0.5 \\
\mathrm{C}=30 \% \\
\mathrm{E}=450.5 \mathrm{MPa} \\
{[\mathrm{mm}]}\end{array}$ & \\
\hline Ballast & 1.993 & 0.401 & 0.253 & 0.231 & 0.552 & 0.542 & 0.309 & $<2$ \\
\hline Sub-ballast & 1.986 & 0.391 & 0.247 & 0.225 & 0.540 & 0.531 & 0.303 & $<2$ \\
\hline $\begin{array}{l}\text { Prepared } \\
\text { Subgrade }\end{array}$ & 1.875 & 0.377 & 0.240 & 0.219 & 0.518 & 0.512 & 0.293 & $<2$ \\
\hline Subgrade & 1.598 & 0.345 & 0.219 & 0.197 & 0.475 & 0.467 & 0.268 & $<2$ \\
\hline \multicolumn{9}{|c|}{$\begin{array}{l}{ }^{(*)} \text { Notese: } \\
\Delta \mathrm{S}_{1-7}-\text { Plaxis-FEM calculated Total Settlements } \\
\text { TS - Tolerable Total Settlement } \\
C \quad \text { - Cement content }\end{array}$} \\
\hline
\end{tabular}


Results have shown that all total settlement values are within the limiting values and that, consequently, each of these mixes could be used. On the other hand, layer thicknesses meeting the same stiffness requirements can be estimated by making a linear correlation between the elastic moduli of six cement-stabilized mixes (C-PSL) and the elastic modulus of the $2 \mathrm{~m}$ thick U-PSL,. Our estimation has shown that the layer thickness can be reduced by up to $70 \%$ by using the highest $\mathrm{E}_{\mathrm{v}}$ value shown in Table 9.

\section{Application of neural networks}

\subsection{General information on artificial neural networks}

An artificial neural network can identify a relationship among specimens and is therefore capable of solving a whole array of complex problems such as specimen recognition, nonlinear modelling, and classification [14]. A three-layered feedforward artificial neural network (ANN or FFNN) is applied in most cases, Figure 9. In this network, input data $\left(x_{i}\right)$ are fed into input layer neurons which, in turn, pass them on to hidden layer neurons $(z)$, after multiplication with the weight coefficient of connection among neurons $\left(v_{i j}\right)[15]$ :

$n e t_{j}=\sum x_{i} v_{i j}-b_{j}$

A hidden layer neuron adds up the weighted input received from each input neuron $\left(x_{i} v_{i j}\right)$, associates it with a bias $(b)$, and then passes the information (net) to the non-linear tangent hyperbolic transfer function [15]:

$f\left(n e t_{j}\right)=\frac{2}{1+e^{-2 n e t_{j}}}-1$

The learning of ANNs is generally accomplished by the back propagation which is the most commonly employed supervised training algorithm. The objective of this algorithm is to obtain the optimal values of the connection weights that would generate an output vector $Y=\left(y_{1}, y_{2^{2}}, \ldots, y_{p}\right)$ as close as possible to the target values of the output vector $T=\left(t_{1}, t_{2}, \ldots, t_{p}\right)$ with the selected accuracy. The optimal weights are found by minimizing a predetermined error function $(E)$ of the following form [15]:

$$
E=\sum_{P} \sum_{p}\left(y_{i}-t_{i}\right)^{2}
$$

where $y_{i}=$ component of the ANN output vector $Y_{i} t_{i}=$ component of the target output vector $T_{i} p=$ number of output neurons; and $P=$ number of training patterns.

In the back propagation algorithm, the signals first flow in forward direction where model produces outputs for each pattern, and then the error is computed. The computed global error is then propagated back towards the input layer during which the values of the weights are updated. The gradient-descent method, along with the chain rule of differentiation, is employed to modify the network weights as follows [15]:

$\Delta v_{i j}(n)=-\delta \frac{\partial E}{\partial v_{i j}}+\alpha \Delta v_{i j}(n-1)$

where $\Delta v_{i j}(n)=$ weight increments between nodes $i$ and $j$ during the $n^{\text {th }}$ iteration, $\Delta v_{i j}(n-1)=$ weight increments between nodes $i$ and $j$ during the $(n-1)^{\text {th }}$ iteration; $d=$ the learning rate and $a=$ the momentum factor (inertia).

The learning rate $(d)$ is used to increase the likelihood of avoiding the training process getting trapped in a local minimum instead of a global minimum. When it is trapped in local minimum, the solution often follows a zigzag path while trying to reach a minimum error, and this may slow down the training process. In such situations, the momentum factor $(a)$ can be employed to speed up training in very flat regions of the error surface and help prevent oscillations in the weights [15].

The network learns by adjusting biases and weights that link its neurons. Before training, weights and biases of the network must be set to small random values. Also, due to the nature of the sigmoid function used in the back-propagation algorithm, all external input and output values should be standardized before passing them into a network. Without standardization, large values of input into an ANN would require application of extremely small weighting factors, and this could cause a number of problems [15]. Since tangent hyperbolic transfer function extends to minus infinity and plus infinity asymptotically, it never reaches -1 or +1 . Therefore, in most cases it is better to compress the data into the -0.9 and +0.9 range. Eq. (5), which compresses all the data into the range of -0.9 to +0.9 , was employed in this study for standardization [15]:

$z_{i}=\left[\frac{1.8\left(x_{i}-x_{\min }\right)}{x_{\max }-x_{\min }}\right]-0.9$

where $x_{\max i}$ and $x_{\text {mini }}$ are the maximum and minimum values of the $t^{\text {th }}$ neuron in the input layer for all feed data vectors, respectively. The details of ANN are given in [15].

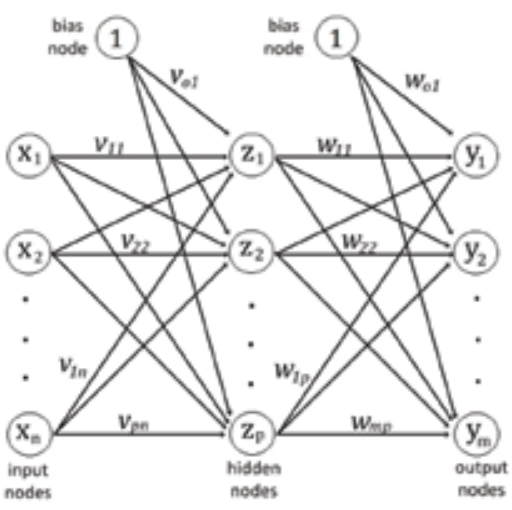

Figure 9. Three-Layer Feed-Forward Artificial Neural Network 


\subsection{Model Predictions}

Three layer feed forward ANN is constructed in order to predict strain, stress, and elasticity in this study. The constructed ANN is used for the three cases where the input vector is the same and the output variable is different for each case, as presented in Figure 10. Out of the total data base, 45 data sets (training stage) were allocated for network training, while 15 data sets (testing stage) were allocated for efficiency evaluation.

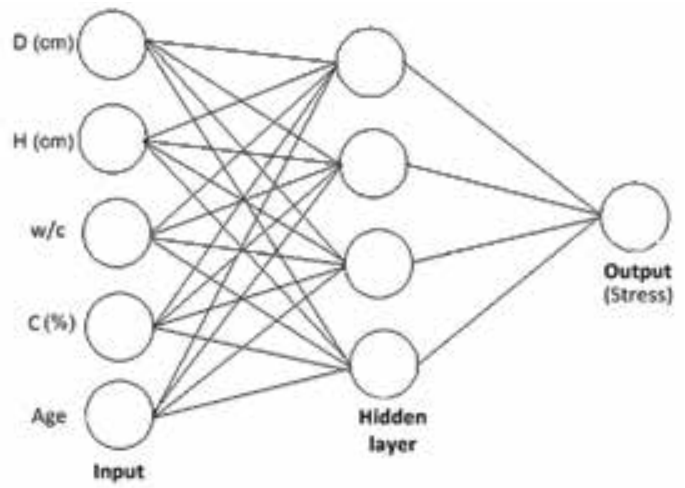

Figure 10. Constructed ANN model

The number of neurons in the input and output layers is fixed due to the specified number of input and output parameters. On the other hand, the number of neurons in the hidden layer the number of epochs (training cycle), the learning rate, and momentum factor values, are decided on by the trial and error procedure. By changing values of these parameters, and keeping track of the error values in each tried case, optimum values of these parameters were selected. This procedure naturally involves many trial combinations, and it would be impossible to present all trial combinations and resulting errors in the scope of this paper. The parameter values that yielded the lowest error for the prediction of stress, strain, and elasticity, are summarized in Table 10.

Table 10. Parameters used in the ANN model

\begin{tabular}{|c|c|}
\hline Parameters & Parameter values \\
\hline Number of neurons in hidden layer & 11 \\
\hline Learning rate & 0.12 \\
\hline Momentum rate & 0.24 \\
\hline Number of epochs & 900 \\
\hline
\end{tabular}

The back propagation training algorithm that employs the gradient decent method is employed in this study. Since the results obtained are satisfactory, we did not try other training algorithms (such as the radial bases NN, conjugate gradient NN, etc) or other ANN configurations such as those involving more than one hidden layer. Sixty sets of data were employed for the ANN training and testing in this study. As presented in Tables 9 and 10, the results imply that the number of data was satisfactory. It is of course desirable to have more data: a greater number of data would positively influence the generalisation capabilities of the trained neural network. Yet, it is not uncommon in literature that a similar $[16,17]$ or lower [18 - 20] number of data sets is used quite successfully.

Table 11 summarizes error measured for the training stage for three cases of stress, strain, and elasticity predictions. For each case, 900 iterations were performed, after which the error function was flat, and there was no need for additional iterations. Table 12 shows model performance results over the testing periods for the stress, strain and elasticity. As can be seen, the model predicts values with low errors and high correlation coefficients for the three cases.

Table 11. Prediction results for training stage

\begin{tabular}{|l|c|c|}
\hline \multicolumn{1}{|c|}{ Training assessment } & MSE & $\mathbf{R}^{2}$ \\
\hline Studied parameters & 0,051 & 0.94 \\
\hline Strain [\%] & 0,011 & 0.96 \\
\hline Elastic modulus [MPa] & 0,014 & 0.95 \\
\hline $\begin{array}{l}\text { MSE - Mean Square Error } \\
\mathbf{R}^{2} \text { - Determination coefficient }\end{array}$ & \\
\hline
\end{tabular}

Table 12. Prediction results for testing stage (generalization)

\begin{tabular}{|l|c|c|c|}
\hline \multicolumn{1}{|r|}{ Evaluation of generalization } & MSE & MAE & $\mathbf{R}^{2}$ \\
\hline Studied parameters & 8.91 & 0.20 & 0.92 \\
\hline $\begin{array}{l}\text { Strain [\%] } \\
\text { Elastic modulus [MPa] }\end{array}$ & 0.12 & 0.31 & 0.96 \\
\hline $\begin{array}{l}\text { MSE - Mean Square Error } \\
\text { MAE - Mean Absolute Error } \\
\mathbf{R}^{2}-\text { Determination coefficient }\end{array}$ & 340 & 139 & 0.90 \\
\hline
\end{tabular}

Bar graphs for predicted measured data for each case are presented in Figures 11-13. As shown in these figures, values predicted according to the model are satisfactory for all cases. Sensitivity analysis has revealed that the proportion of cement is the most sensitive parameter for stress and elasticity. On the other hand, the age is the most sensitive parameter for strain. 


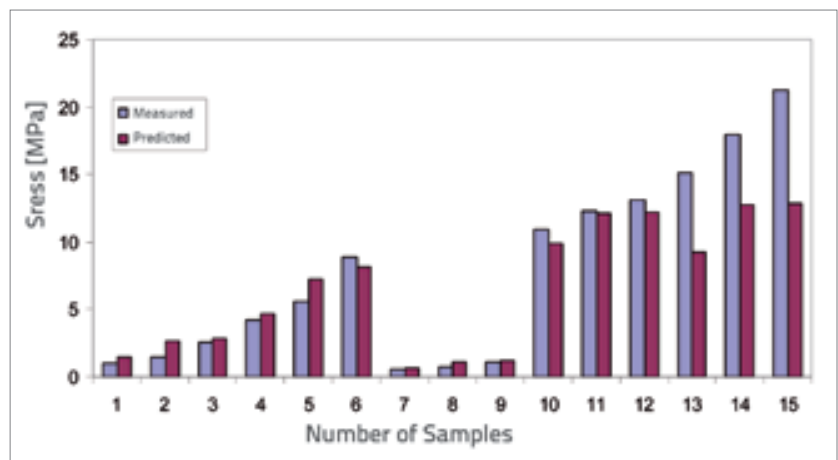

Figure 11. ANN predictions of measured stress values (testing stage)

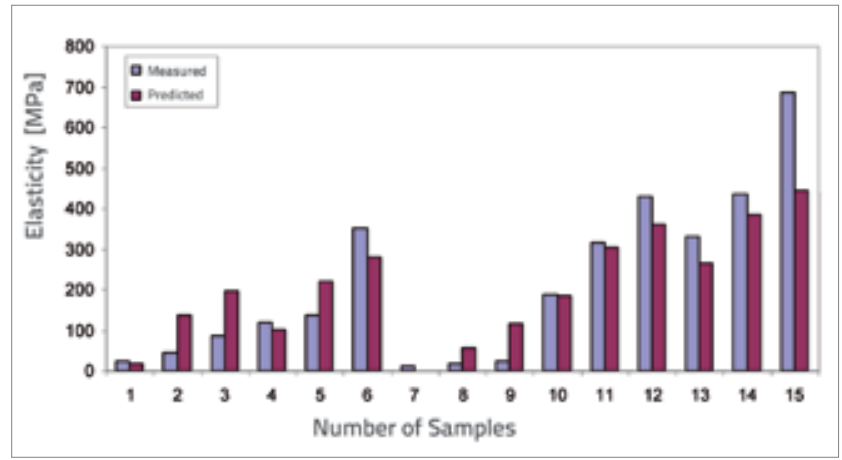

Figure 13. ANN predictions of measured elastic modulus values (testing stage)

\section{Conclusions}

The use of the cement-stabilized subgrade layer instead of the uncemented one in HSR embankments is studied in this paper based on numerical (FEM) and soft computing feed forward neural network (FFNN) methods. The design of HSRE

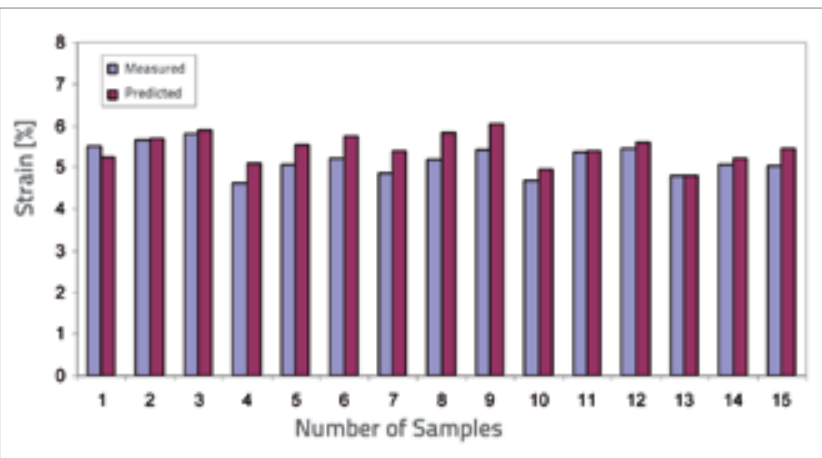

Figure 12. ANN predictions of measured strain values (testing stage)

involves high geometric design standards, good material properties, and very small total differential settlements. Compared to conventional railway fills, HSR embankments are designed to be much stiffer. Laboratory experiments were carried out to determine failure parameters of cemented soil mixes.

The following conclusions can be made:

- Out of ten soil-cement mixes prepared, only six meet stiffness requirements (Table 5).

- The layer thickness can be reduced by about $70 \%$ if C-PSL is used in HSR embankments.

- Artificial neural networks FFNN can be used to predict essential stiffness properties of cement-stabilized HSRE layers (i.e. stress, strain and elastic modulus values).

- Good results have been obtained through the use of back propagation training algorithms using the gradient decent method and tangent hyperbolic activation function in ANN.

- Further studies should be directed toward analysis of aging effect for composite materials subjected to longterm dynamic loads.

\section{REFERENCES}

[1] Egeli, I.: Engineering Consultancy-Internal Report: 'Design and Construction Aspects of High-Speed Train Railway Embankments-An Overview', Taiwan High Speed Railway Construction Project, Taiwan, ROC, 2003.

[2] EN 1991-2: Eurocode 1: Actions on Structures - Part 2: Traffic Loads on Bridges, European Standard: CEN-Cenelec, Brussels, Belgium (www.cenelec.eu), 1991.

[3] Mundrey, J.S.: Railway Track Engineering, 3rd. Ed., Tata-McGrawHill Publ.Co. Ltd., N. Delhi, India, 2008.

[4] Seling, E.T., Waters, J.M.: Track Geotechnology and Substructure Management. Thomas Telford Services Ltd., London, England, 1994.

[5] UIC Report: High Speed Principles and Advantages, International Union of Railway, Paris, France (www.uic.org), 2007.

[6] UIC Code-719R: Earthworks and track-bed layers for railway lines, International Union of Railway, Paris, France (www.uic. org), 1994.

[7] Lakušić, S., Vajdić, M.: Overview of modern track structures on solid bases, GRAĐEVINAR 63 (2011) 2, 125-134.

[8] TS 500: Betonarme Yapıların Hesap-Yapım Kuralları(in Turkish), TSE (www.tse.org.tr), Ankara, Tr., 2000.

[9] TS 706: Beton Agregaları (in Turkish), TSE (www.tse.org.tr), Ankara, Turkey, 2009.

[10] TS 802: Beton Karısımi Tasarım Hesap Esasları (in Turkish), TSE (www.tse.org.tr), Ankara, Turkey, 2009.

[11] TS EN 12390-2: Laboratuvarda Dayanım Deneylerinde Kullanılacak Deney Numunelerinin Hazırlanması ve Kürlenmesi, TSE (in Turkish), Ankara, Turkey, 2002. 
[12] TS EN 12390-3: Deney Numunelerinde Basınç Dayanımının Tayini, TSE (in Turkish), Ankara, Tr., 2003.

[13] Usun, H.: Laboratory Study for Determining Geotechnical Engineering Properties of Cement Treated and Untreated Backfill Soils used in High Speed Railway Embankments, M.Sc. Thesis, Dept.of Civil Engineering, Izmir Institute of Technology, (www.iyte.edu.tr), Urla-zmir,Turkey, 2010.

[14] Farrokhzad, F., Choobbasti, A.J., Barari, A.: Determination of liquefaction potential using artificial neural networks, GRAĐEVINAR 63 (2011) 9/10, 837-845.

[15] Tayfur, G.: Soft Computing in Water Resources Engineering, WIT Press, Sauthampton, United Kingdom, 2012.

[16] Tayfur, G.: Artificial neural networks for sheet sediment transport, Hydrological Sciences Journal, 47 (6): 879-892, 2002.
[17] Tayfur, G., Singh, V.P.: Predicting longitudinal dispersion coefficient in natural streams by artificial neural network, Journal Hydraulic Engineering, 131 (11): 991-1000, 2005.

[18] Akkurt, S., Ozdemir, S., Tayfur, G., et al.: The use of GA-ANNs in the modelling of compressive strength of cement mortar, Cement and Concrete Research, 33 (7): 973-979, 2003.

[19] Tayfur, G., Singh, V.P.: ANN and fuzzy logic models for simulating event-based rainfall-runoff , J. Hydraulic Engineering , 132 (12): 1321-1330, 2006

[20] Erdem, T.K., Tayfur, G., Kirca, O.: Experimental and modeling study of strength of high strength concrete containing binary and ternary binders, Cement Wapno Beton, 16 (4), 224-237, 2011. 